\title{
ELECTRIC SYSTEMS FAILURES PRODUCED BY CG LIGHTNING IN EASTERN AMAZONIA
}

\author{
ANA PAULA PAES DOS SANTOS ${ }^{1}$, JOSÉ RICARDO SANTOS DE SOUZA ${ }^{2}$, EVERALDO \\ BARREIROS DE SOUZA ${ }^{2,3}$, ALEXANDRE DE MELO CASSEB DO CARMO ${ }^{2}$, WANDA MARIA DO \\ NASCIMENTO RIBEIRO ${ }^{2}$
}

\author{
${ }^{1}$ Instituto Nacional de Pesquisas Espaciais, Centro de Ciência do Sistema Terrestre, Grupo de Eletricidade \\ Atmosférica (INPE/CCST/ELAT), São José dos Campos, SP, Brasil. \\ ${ }^{2}$ Universidade Federal do Pará (UFPA), Belém, PA, Brasil. \\ ${ }^{3}$ Instituto Tecnológico Vale (ITV), Belém, PA, Brasil.
}

\begin{abstract}
ana.santos@inpe.br, jricardo@ufpa.br, everaldo.barreiros.souza@itv.org, alxmcc@hotmail.com, wandaribeiro10@hotmail.com
\end{abstract}

Received August 2013 - Accepted April 2014

\begin{abstract}
Operational records of power outages of the electric energy distribution systems in eastern Amazonia presented a large number of events attributed to lightning strikes, during the 2006 to 2009 period. The regional electricity concessionary data were compared to actual lightning observations made by SIPAM's LDN system, over two areas where operational sub systems of transmission lines are installed. Statistical relations were drawn between the monthly lightning occurrence density and the number of power outages of the electric systems for both areas studied. The results showed that, although with some delays between these variables peaks, the number of power disruptions has a tendency to follow the behavior of the lightning occurrence densities variations. The numerical correlations were positive and may be useful to the transmission lines maintenance crews at least for the Belém-Castanhal electricity distribution sub system. Evidence was found, that the SST's over certain areas of the Pacific and Atlantic Oceans, influence convection over the area of interest, and may help to prognosticate the periods of intense electric storms, requiring repair readiness for the regional electric systems.
\end{abstract}

Keywords: Lightning; Electric systems outages; Amazonia.

RESUMO: DESLIGAMENTOS DE SISTEMAS ELÉTRICOS PRODUZIDOS POR RELÂMPAGOS NUVEM-SOLO NA AMAZÔNIA ORIENTAL

Os registros de desligamentos dos sistemas de distribuição de energia elétrica, na Amazônia oriental, apresentaram um grande número de eventos atribuídos à incidência de raios, durante o período de 2006 a 2008. Dados da concessionária regional de energia foram comparados com observações de raios feitas pelo sistema de detecção do SIPAM sobre áreas que abrangem dois subsistemas de linhas de transmissão. Relações estatísticas, entre a densidade mensal de ocorrência de raios e o número de desligamentos dos sistemas elétricos, foram deduzidas para ambos os subsistemas estudados. Os resultados mostraram que apesar de alguns atrasos entre os picos dessas variáveis e o número de desligamentos de energia apresentam uma tendência de acompanhar as variações das densidades de eventos de raios. As correlações numéricas foram positivas e podem ser úteis às equipes de manutenção, pelo menos para o subsistema de Belém-Castanhal. Evidência foi encontrada de que anomalias de TSM, sobre certas áreas dos oceanos Pacífico e Atlântico, influenciam a convecção sobre a área de interesse, e consequentemente, podem ajudar a prognosticar os períodos de intensas tempestades, que necessitam de prontidão para reparos dos sistemas elétricos regionais.

Palavras-chave: Relâmpagos; desligamentos de sistemas elétricos; Amazônia. 


\section{INTRODUCTION}

The operational performance of electric energy distribution systems is susceptible to climatic conditions, and especially vulnerable to strong winds, severe rainfall events and lightning occurrences, near transmission lines (Farias and Correia, 2008; Santos, 2010). In the state of Pará, located in eastern Amazonia, power outages due to these causes are frequent, and there is a need to develop methods to mitigate the resulting economic losses. Moreover, the interconnection of the Brazilian electric energy distribution system with the Tucuruí power generation hydroelectric plant, poses considerable threat of blackouts to large parts of the country, due to lightning strikes on the regional transmission lines and justifies the present study. Since most of the severe weather storms occur in situations of intense atmospheric convection which can be associated to large and meso scales meteorological systems, a climatic prognosis of the appearance of these systems over the area of interest may be helpful to improve the readiness of the systems maintenance crews, before the critical storm periods occur in eastern Amazonia.

Several studies have given evidence of a relation between lightning and rainfall and show that in most cases an increase in rainfall rate corresponds to an increase in lightning frequency of occurrences (Kohn, et al. 2011; Battan, 1965; Carte and Kidder, 1977; Gungle and Krider, 2006; Pessi and Businger, 2009; Tapia et al., 1998; Zhou et al., 2002). This correlation is generally better for higher precipitation amounts (Katsanosa et al., 2007). Studies directed to quantify this relationship revealed that it changes according to a number of factors such as, the stage in the life cycle of the storm (Tapia et al., 1998), the storm type, the peculiarities of the geographic location (Petersen and Rutledge, 1998), the climatic regime (Soriano and De Pablo, 2001) and the lightning type (Soula and Chauzy, 2001). In addition, cloudto-ground (CG) lightning was found to be spatially correlated with the area of higher precipitation (Carte and Kidder, 1977; Soula et al., 1998; Soula and Chauzy, 2001; Tapia et al., 1998). For a given storm case time evolution, it was found that rainfall generally lagged behind the occurrence of lightning by a few minutes (Gungle and Krider, 2006; Piepgrass et al., 1982; Soula et al., 1998). Strong correlation was also found in larger temporal scales, such as monthly and seasonal variations (Price and Federmesser, 2006).

An intrinsic characteristic of the Amazonian climate is its wide spectrum in space and time variability of the convective activity and precipitation. Thus, precipitation is the variable considered the most important to the Amazonian climate characterization. It is known that most of the annual precipitation in Amazon occurs during the Southern Hemisphere summer and fall seasons (Figueroa and Nobre, 1990; Marengo et al., 2001;
De Souza and Ambrizzi, 2003), mainly associated to largescale quasi-stationary atmospheric circulations patterns which produce the atmospheric systems known as the Intertropical Convergence Zone (ITCZ) and the South Atlantic Convergence Zone (SACZ). The Atlantic ITCZ plays a predominant role in the modulation of the rainfall regime near the equator and essentially determines the period of the local rainy season, particularly in the Amazon and northeastern region of Brazil (Lopes, 2009). On the other hand, the SACZ is an intra-seasonal meteorological phenomenon which directly influences the rainfall distribution in most South American tropics and sub-tropics (Kodama, 1992; Quadro, 1994; Nogues-Paegle and Mo, 1997; Liebmann et al. 1999). During the summer and early fall months is common the joint action (coupling of the tropical convective cloudiness bands) of the SACZ and ITCZ, including the presence of others meteorological systems such as the Bolivian High (BH) and the High Levels Cyclonic Vortices (Gan and Kousky, 1986), thereby resulting in occurrences of intense thunderstorm episodes over this area (De Souza and Ambrizzi, 2003).

Studies have shown that the tropical ocean currents and sea surface temperature (SST), behaviors, are the main modulators of the earth's climate, in both global and regional scales (Grimm, et al. 1998, De Souza, et al. 2000). The climatic conditions over the Brazilian eastern Amazon region are clearly influenced by the SST anomalies over the equatorial Pacific Ocean, as well as, by the meridional anomalous SST mode, observed on the intertropical Atlantic Ocean (De Souza, et al. 1999). Positive or negative increments of the SST over the equatorial Pacific strip, of about $0.5^{\circ} \mathrm{C}$ or more, lasting for more than five consecutive months, characterize the phenomena known as El Niño and La Niña. Even the smaller anomalies which cause these phenomena are already sufficient to change the atmospheric general circulation patterns, in particular the Walker cell, which influences the convection dynamics and rainfall regime in the northeastern region of Brazil (De Souza, et al. 2009).

Waliser and Gautier (1993) mentioned the importance of the abovementioned systems for the global and regional climate. Moreover, they pointed out that the interactions of these systems with the tropical Atlantic surface conditions directly determine the duration and intensity of the regional rainy season. These interactions often produce meso-scale meteorological systems such as the Squall Lines, which may account for up to $45 \%$ of the total precipitation in eastern Amazon (Cohen, et al. 1989).

The meteorological conditions described above produce a large and almost continuous cloud cover over the Amazon region, in particular cumulonimbus having ice tops which produce high rates of lightning events (Teixeira et al, 2011). Some peculiarities of the regional lightning flashes have been studied and there is indication that the peak currents of their 
strokes have median values higher than elsewhere in the world (Almeida et al. 2012). Additionally, the regional density of occurrence of lightning events is high and influenced by seasonal features (Rocha et al, 2007) and the type of land surface.These characteristics of the regional lightning events pose considerable threat to disrupt human activities, in particular to the local telecommunication and electric systems (Ribeiro et al, 2011). In recent years there is growing evidence that due to climate changes, extreme weather events, including severe lightning storms are becoming more frequent and/or intense (Kohn et al., 2011).

The CG lightning occurrences are the main cause of electric systems power outages according to the registers of failures of the Brazilian electricity concessionaires. Nevertheless the quantification of such relationship has not yet been made for the Amazonian electric systems. This work seeks to shorten this gap by analyzing the climatic context and some meteorological aspects prevailing during increasing number of episodes of electric systems power outages in eastern Amazonia. In order to do so, the authors had access to the failures spreadsheets of the Pará state electricity distribution concessionary and lightning occurrence data obtained simultaneously by the Amazonian Protection System, Lightning Detection Network (SIPAMLDN). In addition to this contribution, this work aimed to determine the sea surface temperatures (SST) anomalies over the equatorial Pacific and tropical south Atlantic Oceans and meteorological systems which propitiated above normal regional lightning storms numbers. One expects that this knowledge may lead to future prognostic warnings to the electricity company's maintenance personnel to improve their repair readiness.

\section{MATERIAL AND METHODS}

Two main sets of data were used for this research: 1- The power outages register spreadsheets provided by the Pará state electricity concessionary ( CELPA Redenergia S.A.) and 2- The lightning flash events detected and located by the SIPAM's-LDN. The CELPA's spreadsheets included only, non programmed disruptions of its distribution system. These failures were divided in two types of causes: lightning strikes on, or near, the transmission lines and other failure causes, known or not. The lightning produced failures were set apart for this analysis. The SIPAM's 'LDN integrated 12 LPATS IV sensors manufactured by VAISALA, partially operating during the period of this study, which included the years of 2006 to 2008. This system's sensors were installed at sites belonging to four Brazilian states and covered most of the eastern Amazonia (Ribeiro, 2010). Its data collection, detection efficiency and other characteristics were described by Almeida et al. 2012.

The CELPA's system has separate failures data spreadsheets for each one of its operational sub systems. Such is the case for the sub systems of Belém, Castanhal, Marabá and others, which have their own voltage reducing sub stations, and low tension electricity distribution lines. Considering the fact that Castanhal is only $80 \mathrm{~km}$ away from Belém, data sub sets corresponding to the sub systems of Belém and Castanhal were integrated and denominated as Area 1 and that of Marabá was designated as Area 2 (Figure 1), for further statistical analysis. These so designated areas of study are quite different regarding their population densities and consequently the actual branching

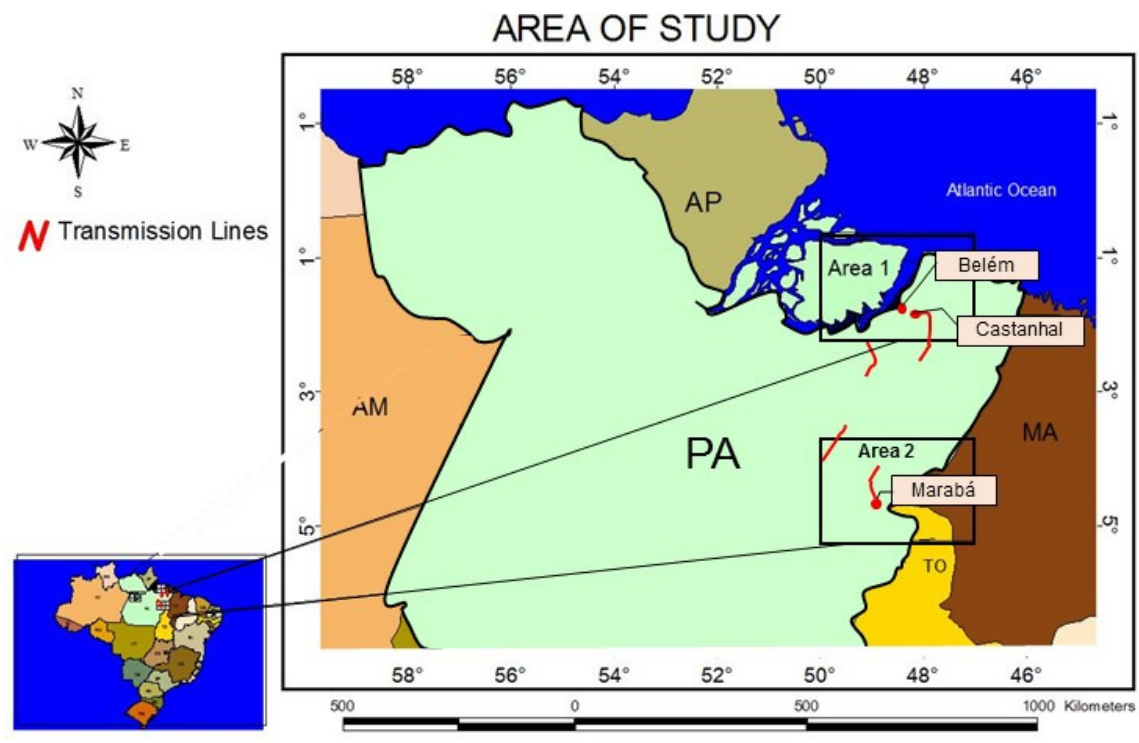

Figure 1 - Geographic location of the studied areas: Area 1 (Belém and Castanhal sub systems) and Area 2 (Marabá sub system). A few segments of the high voltage transmission lines mapped on the field by the authors are shown. The low voltage network of CELPA's distribution lines cannot be displayed at the scale of this figure. 
of their energy distribution lines. Area 1 shown in Figure 1 has approximately 4 million inhabitants while Area 2 has less than 500.000 people and short ranging low tension transmission lines. The two areas have the same size in order to compare the number of CG lightning flashes and eventual seasonal differences of this variable between them.

The corresponding positions of the lightning events observed by the SIPAM LDN at the times of the power failures of the electric sub systems considered, were selected through the Arc View 3.2 and MatLab softwares within the two rectangles, comprehending part the northeast and of the southeast of the Pará, to confirm that they happened within the same areas. EXCEL spreadsheets of these two variables data (lightning occurrence number versus number of power failures) were used to perform the statistical analysis and display the results on the corresponding figures.

A statistical analysis was made in terms of the percentiles method, in order to select the months with larger number of power outages. The months in which these disruptions exceeded the 50th percentile received special attention in the analysis. Taking into consideration only these months a survey was made to find out whether the associated atmospheric discharges activity were also above normal. In order to do so, the correlation coefficients between these variables were determined. Another approach was to find out whether a similar tendency of the variables increments existed. A moving average filter was applied before displaying the results. These time tendencies were quantified by determining the correlation coefficients between the filtered data of the two variables.

Eventual remote influences of the SST's of the equatorial Pacific and tropical south Atlantic oceans on the cloudiness over the studied area were considered. A table was made up showing the SST's anomalies signs observed during the months with larger numbers of power outages registered. In order to determine what situation favors or inhibits intense convection in the regional atmosphere, a frequency of a given pattern was determined as a probable teleconnetion among these variables.

\section{RESULTS}

Figure 2a displays the monthly total electric sub system failures for the two areas studied, during the 2006 to 2008 period. It may be observed that the power outages present a seasonal behavior, with larger disruption numbers occurring between the end of spring up to the middle of the southern hemisphere autumn. This period coincides the months of greater convective activity in the region, which in its turn produces larger increments of the lightning occurrence frequency and probability of direct strikes on the regional electricity transmission lines. On the other hand, the lowest failure numbers were observed mainly during the southern hemisphere winter, when the atmosphere over the region is more stable and the events of lightning strikes on the transmission lines are less likely. Still in the same Figure the horizontal line indicates the median of the monthly values for the period of study or the 50th percentile level. The months presenting power outages numbers above this level, were selected more detailed analysis regarding their eventual relationship with the lightning occurrence frequency further on in Figures 3 to 6.

Figure $2 \mathrm{~b}$ shows the total annual number of Power outages registered by each electricity distribution sub system comprehended by Areas 1 and 2. The disruptions maxima were of 287 events for Area 1 in 2007 and 231 outages for Area 2 in 2006. The Area 1 sub system presented a greater number of failures in all three years of observations. This fact may be attributed both to the higher density of lightning occurrences near the mouth

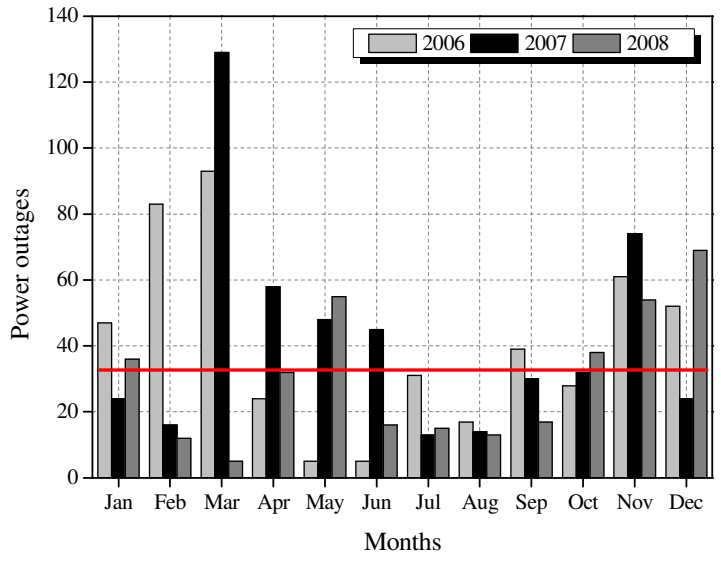

(a)

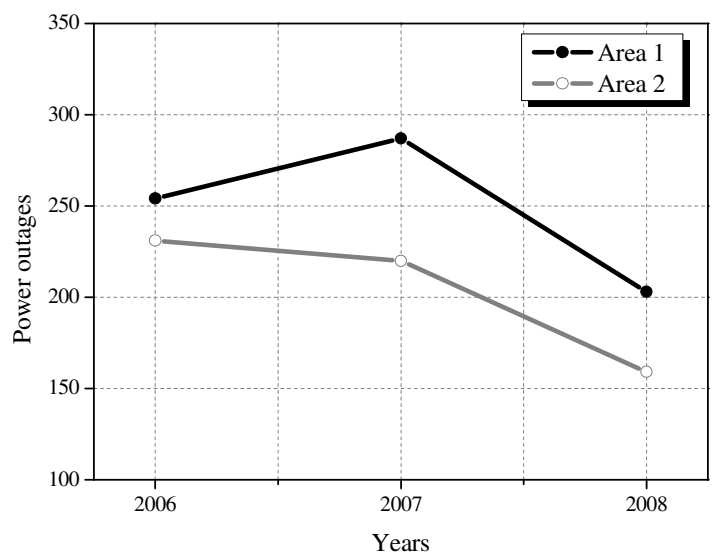

(b)

Figure 2 - Number of Power outages of the electric sub systems in eastern Amazonia: (a) Monthly total distributions for Areas 1 and 2 - the horizontal line indicates the $50^{\text {th }}$ percentile level; (b) Annual totals distributions foar Areas 1 and 2 (Data Source: CELPA Redenergia Co.). 
of the Amazon River (Teixeira et al. 2011) and to the greater branching of the transmission lines in this more populated area, making lines more prone to lightning strikes. Overall, one may say that the two sub systems exhibited similar failure behavior in the period, with significant drop in values in 2008.

\subsection{Area 1}

Hereafter the two areas will be analyzed separately, with regard to relationship between the CG lightning occurrence number and the number of electric energy outages. As mentioned before, only months with elevated failures, that is, those whose failures exceeded the the $50^{\text {th }}$ percentile value will be considered. However, the months of January, February, March and November of 2006, which fell into this criterion, had to be discarded from the analysis because the SIPAM's LDN was not operating satisfactorily then. With this restriction, the Figure 3a shows the distributions of lightning and power outage numbers, for the selected months. It appears that except for the variations between December and March of 2006, the two variables time evolution was quite similar. This fact encouraged the authors to seek a regression relation between these two variables. The result is displayed in Figure $3 \mathrm{~b}$. The best fit between the two variables was a polynomial equation represented by $\mathrm{y}=-4 \mathrm{E}-07 \mathrm{x}^{2}+0.0069 \mathrm{x}+14.623$. Where, $\mathrm{y}=$ Power outages and $\mathrm{x}=$ lightning.

The regression and determination coefficients were found to be 0.69 and 0.63 , respectively. These values indicate that there was a good relation between the lightning flash occurrence number and the number of disruptions of the electric sub system operating in Area 1, at least for the months with above normal number of failures.

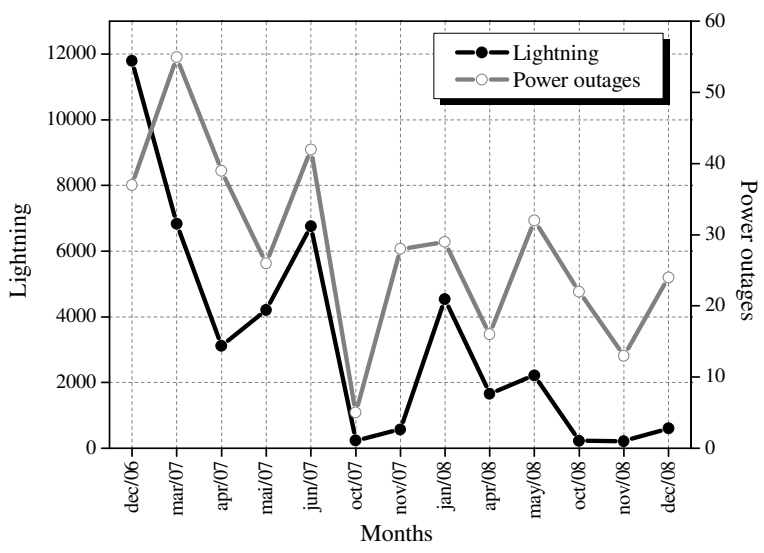

(a)
In order to highlight the tendencies between the lightning and power outage numbers, a moving averages (MA) filter, between pairs of values and the result placed at the second position, was applied to the previous data displayed in Figure 3a. The resulting relationship is shown in Figure 4a. The data processed this way led to an even better correspondence between the increments of the two original variables. A regression between the values derived from the MA is displayed in Figure $4 \mathrm{~b}$, where the continuous curve represents the best fit polynomial equation given by: $y=-1 \mathrm{E}-07 \mathrm{x}^{2}+0.0045 \mathrm{x}+16.358$. Where, $\mathrm{y}=$ power outages and $\mathrm{x}=$ lightning.

The correlation and determinations coefficients found were: 0,87 and 0,76 , respectively. These values indicate that the inclusion of a longer time series of data can improve the statistical relation between the lightning occurrence frequency observed and the number of disruptions of the electric subsystem operating in Area 1.

\subsection{Area 2}

Figure 5 shows the monthly values, above the 50 th percentile level, of lightning produced power outages and the lightning occurrence numbers in the Area 2, corresponding to the electricity distribution subsystem of Marabá. One may note in Figure 5a that, in spite of some similarities of the general behaviors of these two variables, the number of coincidences and discrepancies of their time increments is nearly the same. Additionally, in some months such as December, 2006 and November, 2007 these variables presented quite discrepant values. In this last case ; one possible explanation for the discrepancy may be grounding deficiencies in the Marabá system, which became more evident during the drier months of

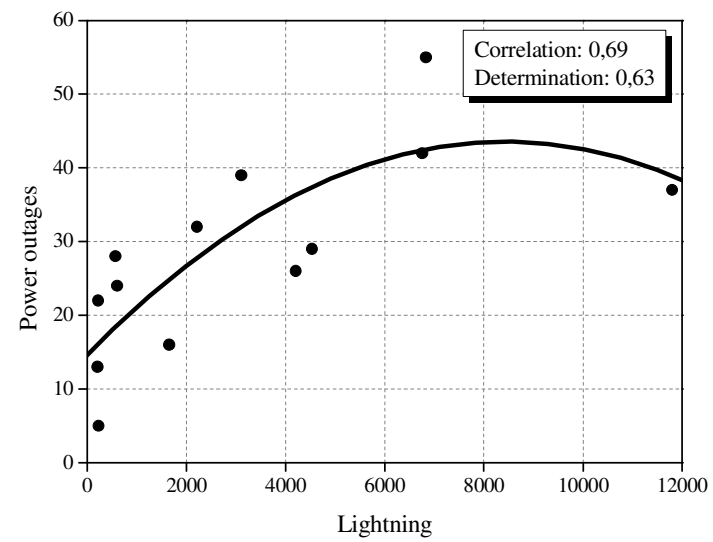

(b)

Figure 3 - Lightning versus power outage numbers- for Area 1 - Belém-Castanhal-months with failure numbers above the $50^{\text {th }}$ percentile level: (a) Time distribution of the occurrences (b) polynomial regression between the two variables (Data sources: CELPA Redenergia Co. and SIPAM's LDN). 
the year when the soil's resistivity rises, making the transmission systems more vulnerable to lightning strikes. These divergences certainly would be reflected in the following regression analysis.

Figure $5 \mathrm{~b}$, indicates that the correlation and determination coefficients were 0.19 and 0.13 , respectively. This indicates a low relationship between the two variables in Area 2 , during the period considered. The best fit obtained in this case was given by the polynomial equation, $y=-6 \mathrm{E}-08 \mathrm{x}^{2}+0.0026 \mathrm{x}+$ 15.606 represented by the curve in Figure $5 b$. Where, $y=$ power outages and $\mathrm{x}=$ lightning.

Even acknowledging the low values of the coefficients derived from the statistical adjustment between these variables for Area 2, an attempt was made to find out their relative tendencies, by applying the MA procedure on their time variations. The results of this filtering are presented in Figure 6. Overall, one may say from Figure $6 a$, that a similar tendency appears to exist between these variables, except for the large discrepancy observed in November, 2007. The large number of electric failures registered in that month led also to poor results of the numerical fitting of the data even when processed through the MA. These results are presented in Figure $6 \mathrm{~b}$. The correlation and determination coefficients were 0.50 and 0.25 , respectively, in this case The best fit between the MA of the lightning and power outage data provided the polynomial equation: $y=-8 E-09 x^{2}+0.0008 x+19.937$. Where, $y=$ power outages and $\mathrm{x}=$ lightning.

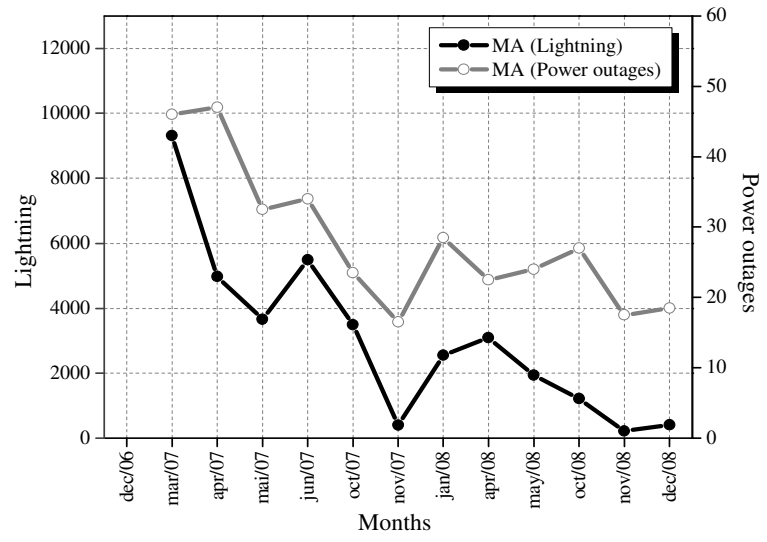

(a)

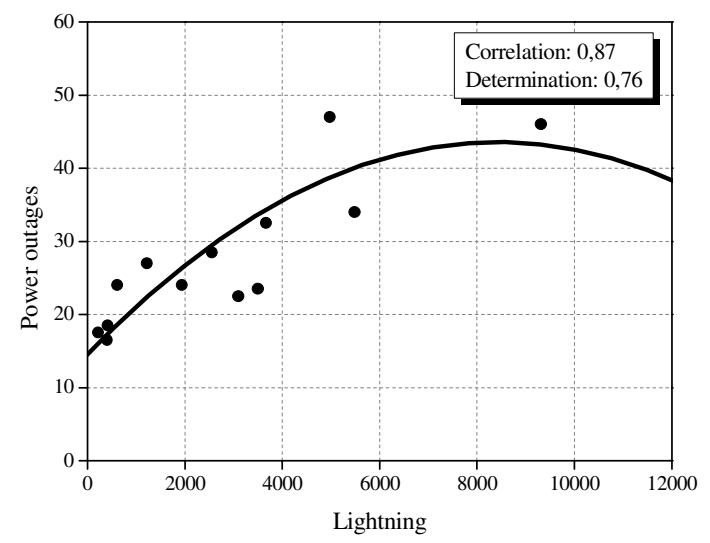

(b)

Figure 4 - Moving averages (MA) of lightning versus power outage numbers- for Area 1 - Belém-Castanhal - months with failure numbers above the $50^{\text {th }}$ percentile level: (a) Time distribution of the occurrences (b) polynomial regression between the two variables (Data sources: CELPA Redenergia Co. and SIPAM's LDN).

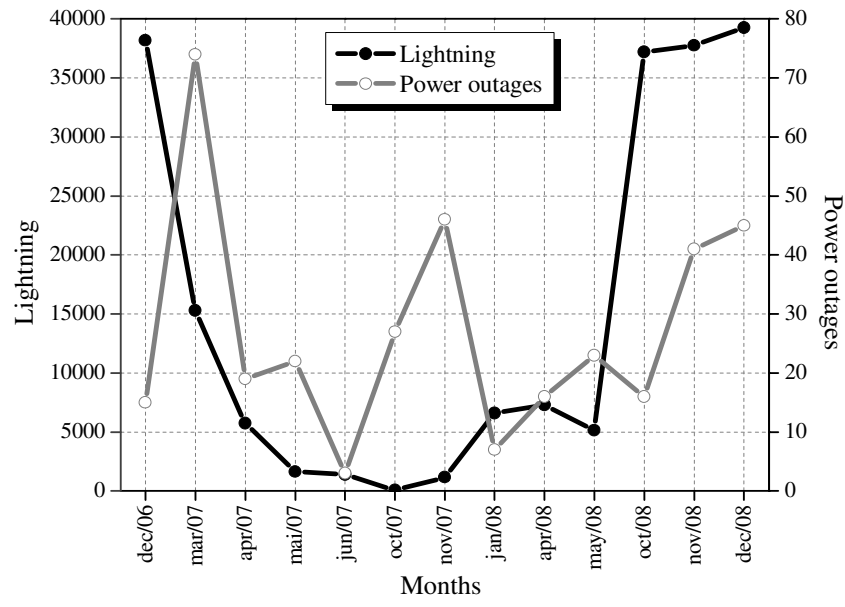

(a)

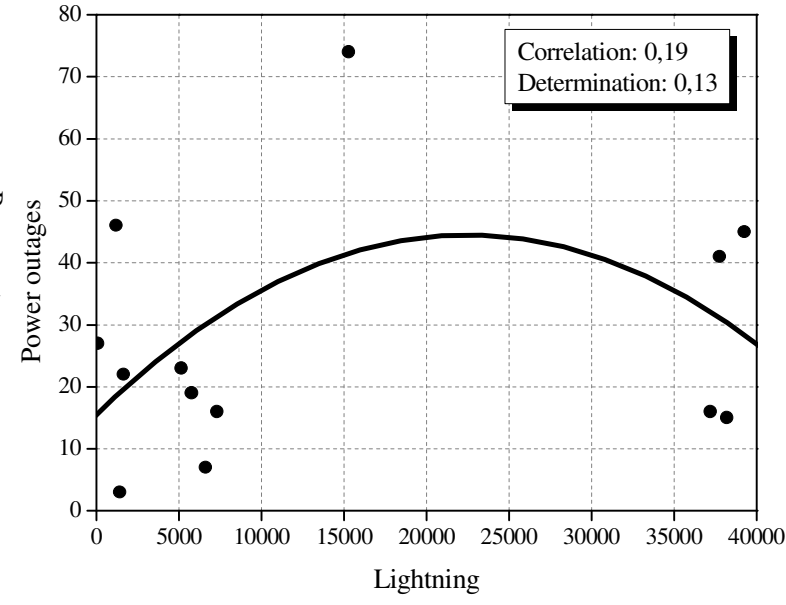

(b)

Figure 5 - Lightning versus power outage numbers- for Area 2 - Marabá - months with failure numbers above the 50th percentile level: (a) Time distribution of the occurrences (b) polynomial regression between the two variables (Data sources: CELPA Redenergia Co. and SIPAM's LDN). 


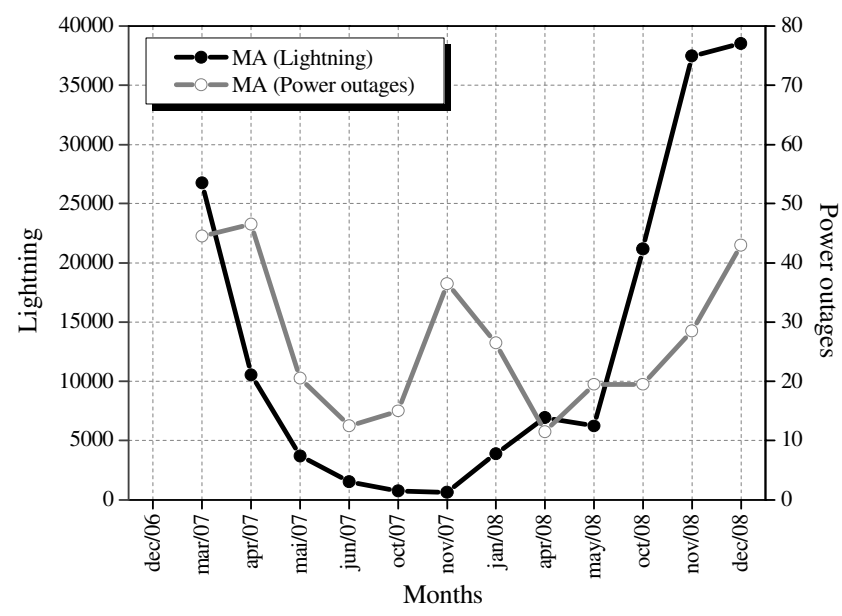

(a)

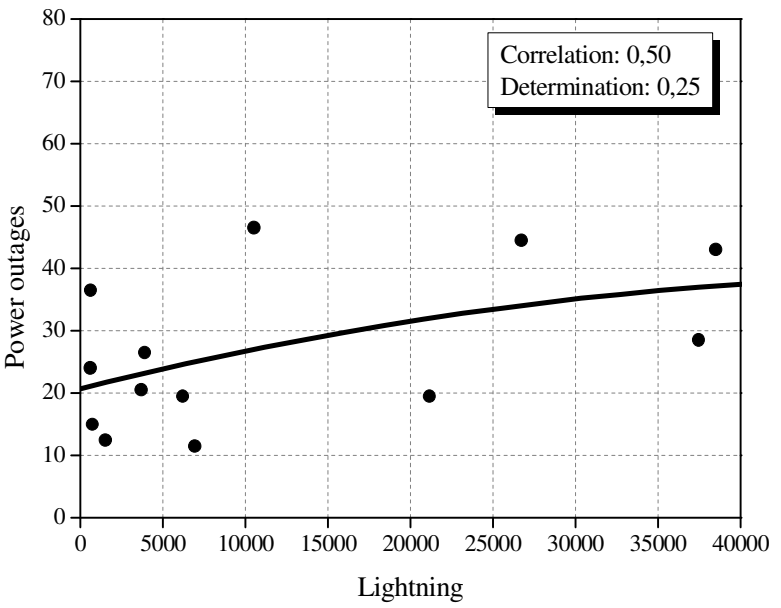

(b)

Figure 6 - Moving averages (MA) of lightning versus power outage numbers- for Area 2 - Marabá - months with failure numbers above the 50th percentile level: (a) Time distribution of the occurrences (b) polynomial regression between the two variables (Data sources: CELPA Redenergia Co. and SIPAM's LDN ).

Again, the MA filtering approach, improved the regression results with respect to the original data. Nevertheless, the correlation level was lower than that obtained for the Area 1 and may be considered insufficient for practical applications by the regional electricity concessionary. It should be pointed out that the abnormally high number of power outages versus very low lightning flash number detected in November, 2007, was also observed for Area 1 (Figure 3a). This fact reinforces the previous hypothesis of the soil's resistivity rise and insufficient grounding of the electric systems during the local dry period of the year. Another possibility is that the SIPAM's LDN might have had a smaller lightning detection efficiency in that particular month.

The larger incidence of lightning over the electric systems in Area 1 with regard to the Area 2, is due to a composite effect of larger lightning densities of occurrences in the areas surrounding Belém and Castanhal and the fact that the Marabá's electric system is much less branched than that of Area 1, therefore less likely to be stroked by lightning flashes.

\subsection{The SST Influence}

The Table 1 presents the equatorial Pacific and tropical south Atlantic oceans patterns of SST anomalies prevailing at each month of high number of power outages, selected for this study. It was observed that for all months selected in 2007 and January of 2008, the SST anomalies were negative, that is, the SST over the Pacific were cooler and favored the formation of deep convection in the areas of this study. In the other months (December, 2006, April, May, October, November and December, 2008) the SST's anomalies were positive which would inhibit convection in the region. However, the tropical south Atlantic exhibited positive anomalies in these months, which favors the formation of convection in the studied region. This second influence seems to prevail over the eventual negative convection effect of the equatorial Pacific.

Figure 7 presents a diagram of the frequency of influence each ocean on the thunderclouds formation over the area of interest. The equatorial Pacific presented a favorable pattern

Table 1 - Situation of the observed SST in the equatorial Pacific and south tropical Atlantic, during the period of power outages of the CELPA systems (NA= Negative Anomaly; PA= Positive Anomaly). (Source of the data: NCEP/NCAR).

\begin{tabular}{|c|c|c|c|c|c|c|c|c|c|c|c|c|c|}
\hline Pacific & $\mathrm{PA}$ & NA & NA & NA & NA & NA & NA & NA & $\overline{\mathrm{PA}}$ & PA & PA & PA & PA \\
\hline Atlantic & PA & PA & PA & PA & PA & PA & PA & PA & PA & PA & PA & PA & PA \\
\hline 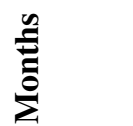 & $\begin{array}{l}8 \\
\text { பू } \\
0\end{array}$ & $\begin{array}{l}\hat{0} \\
\dot{\bar{t}} \\
\sum\end{array}$ & $\begin{array}{l}5 \\
\stackrel{0}{2}\end{array}$ & $\begin{array}{l}5 \\
\text { a } \\
\text { i }\end{array}$ & $\begin{array}{l}\mathbf{s} \\
\Xi\end{array}$ & 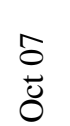 & $\begin{array}{l}\hat{0} \\
\text { a } \\
z\end{array}$ & 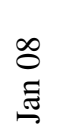 & $\begin{array}{l}\infty \\
0 \\
\stackrel{\bar{Z}}{\mathbb{Z}}\end{array}$ & 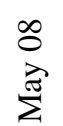 & $\begin{array}{l}\infty \\
\stackrel{0}{0} \\
0\end{array}$ & $\begin{array}{l}\infty \\
0 \\
z \\
\mathbf{z}\end{array}$ & $\begin{array}{l}\infty \\
0 \\
U \\
\mathscr{D}\end{array}$ \\
\hline
\end{tabular}




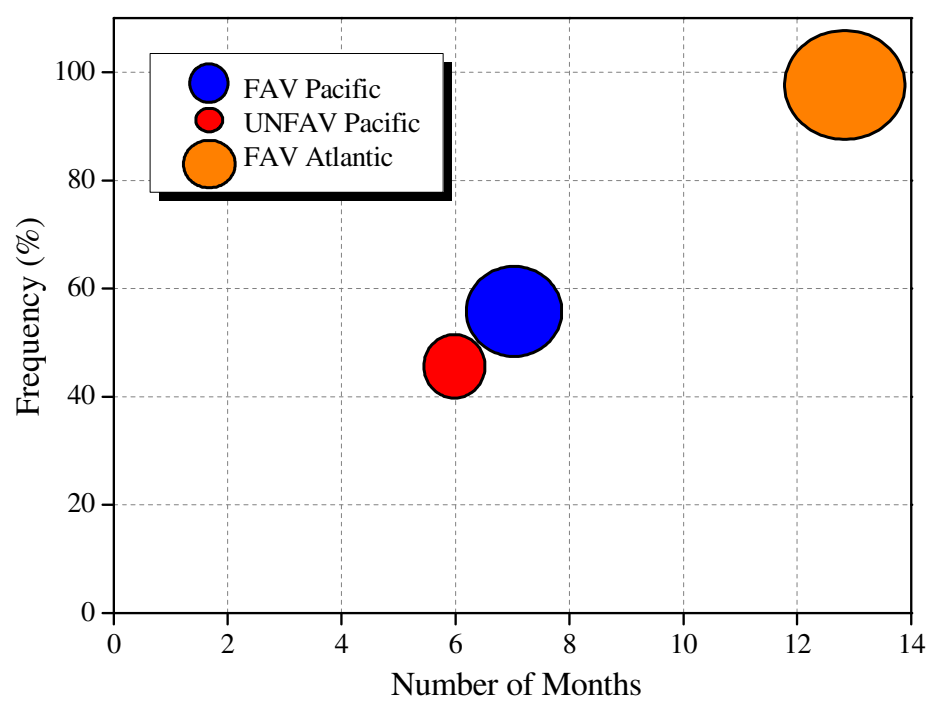

Figure 7 - Diagram of the influence of the SST anomalies over the equatorial Pacific and tropical south Atlantic oceans on the thundercloud formation in the eastern Amazonian region; during the months of large failure number of its electric energy systems. (Data source: NCEP/NCAR).

during 7 months, that is, $54 \%$ of the period with increased power outage frequency. During 6 months, that is $46 \%$ of the months it presented unfavorable anomalies. On the other hand, the tropical south Atlantic presented anomalies favorable to the thunderclouds formation in the region in all months selected, that is, $100 \%$ of the cases analyzed.

\section{CONCLUSIONS}

The simultaneous behavior of a time series of power outages and CG lightning frequency of occurrences over two areas of eastern Amazonia, were analyzed.This work has demonstrated that a relation between these variables exist and can be quantified for pratical applications. The statistical correlations produced best fitting through polynomial equations drawn for months of elevated power failure numbers; that is above the 50th percentile of the median of occurrences. The correlation coefficiets indicated better results for one of the areas located at northeast of the state of Pará which presents higher lightning density of occurrences and a more branched transmision lines distribution than another area towards the south of the State. For this specific area, the results were not satisfatory for use by the regional electricity concessionary. A moving averages filtering of the original data showed a better adjustment between the two variables tendencies. This indicates that a time series of data longer than the three years analyzed may produce even better statistical fittings. A survey of the SST's anomalies over the equatorial Pacific ocean indicated that they were favorable to the thunderclouds formation in eastern Amazonia during 54\% of the selected stormy months and $46 \%$ unfavorable to that condition.
Simultaneously, the SST's anomalies over the tropical south Atlantic were favorable to regional thunderclouds during all months selected in the period of this study. Considering the latter evidence, one could use the positive SST anomalies of the south Atlantic ocean to prognosticate months of elevated lightning incidence over the areas of interest. This can alert for necessary repair readiness by the electric systems maintenance crews of the regional electricity concessionary, in order to diminish the power outages intervals.

\section{ACKNOWLEDGEMENTS}

The authors thank the Federal University of Para for the infrastructure made available to them. They acknowledge the use of data provided by The Amazonian Protection System Agency, The CELPA Redenergia Co. and the National Center for Environmental Prediction. The authors also thank The Brazikian Research and Projects Financier for the research grant provided to the Amazonian Monitoring Network Project - REMAM II, FINEP- and the fellowships from CAPES and CNPq.

\section{REFERENCES}

ALMEIDA, A.C.; ROCHA, B.P.; SOUZA, J.R.S.; SÁ, J.A.S.; PISSOLATO FILHO, J.A. Cloud-to-Ground Lightning Observations over the Eastern Amazon Region. Atmospheric Research, v.117, 1, p. 86-90. 2012.

BATTAN, L.J. Some factors governing precipitation and lightning from convective clouds. Journal Atmospheric Science. v.22, p.79-84. 1965. 
CARTE, A.E., KIDDER, R.E. Lightning in relation to precipitation. Journal of Atmospheric and Solar-Terrestrial Physics, v. 39, p. 139-148. 1977.

COHEN, J. C. P; DIAS, M. A. F. S.; NOBRE, C. A. Aspectos climatológicos das linhas de instabilidade na Amazônia. Climanálise - Boletim de Monitoramento e Análise Climática, v.4, n.11, p.34-40. 1989.

DE SOUZA, E. B.; ALVES, J. M. B.; XAVIER, T. M. S. Distribuição Mensal e Sazonal da Precipitação no Semiárido Nordestino Durante os Anos de Predominância de Aquecimento ou de Resfriamento Observado em toda a Bacia do Atlântico Tropical. Revista Brasileira de Meteorologia, v.14, n.1, p. 01-09. 1999.

DE SOUZA, E. B. et al. On the influences of the El Niño, La Niña and Atlantic dipole pattern on the Amazonian rainfall during 1960-1998. Acta Amazônica, v.30, n.2, p.305-318. 2000.

DE SOUZA, E. B.; AMBRIZZI, T. Pentad precipitation climatology over Brazil and the associated atmospheric mechanisms. Climanálise - Boletim de Monitoramento e Análise Climática, v.1. 2003.

DE SOUZA, E. B. et al. Precipitação Sazonal sobre a Amazônia Oriental no Período Chuvoso: Observações e Simulações Regionais com o REGCM3. Revista Brasileira de Meteorologia, v.24, n.2, 111-124, 2009

FARIAS, W.R.G. CORREIA, M.F. Descargas atmosféricas e interrupções de energia elétrica na área da CHESF: Relação com Variáveis atmosféricas em anos de El Niño e La Niña. Revista Brasileira de Meteorologia, v.23, n.3, p.270-281, 2008.

FIGUEROA, S. N.; NOBRE, C. A. Precipitation distribution over central and western tropical South America. Climanálise - Boletim de Monitoramento e Análise Climática, v.5, p.3645. 1990.

GAN, M. A.; KOUSKY, V. E. Vórtices ciclônicos da alta troposfera no oceano Atlântico Sul. Revista Brasileira de Meteorologia, v.1, p.19-28. 1986.

GRIMM, A. M.; FERRAZ, S. E. T.; GOMES, J. Precipitation Anomalies in Southern Brazil Associated with El Niño and La Niña Events. Journal of Climate, v.2, p.2863-2980. 1998.

GUNGLE, B., KRIDER, E.P. Cloud-to-ground lightning and surface rainfall in warm-season Florida thunderstorms. Journal of Geophysical Research. 111. 2006.

KATSANOSA, D., LAGOUVARDOSA, K., ARGIRIOUB, A., KOTRONIA, V. Combined analysis of rainfall and lightning data produced by mesoscale systems in the central and eastern Mediterranean. Atmospheric Research, v. 83, p.55-63. 2007.

KODAMA, Y. Large-scale common features of subtropical precipitation zones (the Baiu frontal zone, the SPCZ, and the SACZ). Journal of the Meteorological Society of Japan, v.70, n.4, p.813-836. 1992.

KOHN, M., GALANTI., E. PRICE, C., LAGOUVARDOS. K., KOTRONI. Nowcasting thunderstorms in the Mediterranean region using lightning data. Atmospheric Research, v.100, p. 489-502. 2011.

LIEBMANN, B. et al. Submonthly convective variability over South America and the South Atlantic convergence zone. Journal of Climate, v.12, p.1877-1891. 1999.

LOPES, M.N.G. Aspectos Regionais da Variabilidade de Precipitação no Estado do Pará: Estudo Observacional e Modelagem Climática em Alta Resolução. 2009. 117 f. Dissertação (Mestrado em Ciências Ambientais) Universidade Federal do Pará, Belém, 2009.

MARENGO, J. A. et al. Onset and end of the rainy season in the Brazilian Amazon Basin. Journal of Climate, v.14, p.833-852. 2001.

NOGUÉS-PAEGLE, J.; MO, K. C. Alternating wet and dry conditions over South America during summer. Monthly Weather Review, v.125, p.279-291. 1997.

QUADRO, M. F. L. Estudo de episódios de Zona de Convergência do Atlântico Sul (ZCAS) sobre a América do Sul. 1994, 123f. Dissertação (Mestrado em Meteorologia) - Instituto Nacional de Pesquisas Espaciais, INPE, São Paulo. 1994.

PESSI, A.T., BUSINGER, S. Relationships among lightning, precipitation, and hydrometeor characteristics over the North Pacific Ocean*. American Meteorological Society, v. 48, p. 833-848, 2009.

PETERSEN, W. A.; RUTLEDGE, S. A. On the relationship between cloud-to-ground lightning and convective rainfall. Journal of Geophysical Research: Atmospheres (19842012), v. 103, n. D12, p. 14025-14040, 1998.

PIEPGRASS, M.V., KRIDER, E.P., MOORE, C.B. Lightning and surface rainfall during Florida thunderstorms. Journal of Geophysical Research, v. 87, p. 11,193-11,201, 1982.

PRICE, C., FEDERMESSER, B. Lightning-rainfall relationships in Mediterranean winter thunderstorms. Geophysical Research Letters, v.33, L07813. 2006.

RIBEIRO, W.M.N. Distribuição de Raios, Precipitação e Casos de Tempestades Severas na Amazônia Oriental. 2010. Dissertação (Mestrado em Ciências Ambientais) Universidade Federal do Pará, Belém, 2010.

RIBEIRO, W.M.N. et al. Lightning and Precipitation Distributions over Different Surface Types, in Eastern Amazonia. In: XVI International Conference on Atmospheric Eletricity, 2011, Anais... Rio de Janeiro-RJ-Brasil , 08 a 12 de agosto.

ROCHA, B.R.P.; et al .2007. Lightning Characteristics Time Distribution over Four Locations in Eastern Amazonia. In: 
IX International Symposium on Lightning Protection, 2007. Anais...Foz do Iguaçú-PR-Brazil, 26 a 29 de November.

SANTOS, A.P.P. Raios e Precipitação na Amazônia Oriental: Efeitos no Sistema Elétrico. 2013. 57 f. Trabalho de Conclusão de Curso (Graduação em Meteorologia) Universidade Federal do Pará. 2010.

SORIANO, L.R., DE PABLO, F. Relationship between convective Precipitation and cloud-to-ground lightning in the Iberian Peninsula. Monthly Weather Review-American Meteorological Society, v. 129, p. 2998-3003. 2001.

SOULA, S., CHAUZY, S. Some aspects of the correlation between lightning and rain activities in thunderstorms. Atmospheric Research, v. 56, p. 355-373. 2001.

SOULA, S., SAVAGEOT, H., MOLINIE, G., MESNARD, F., CHAUZY, S. The CG lightning activity of storm causing a flashflood. Geophysical Research Letters, v. 25, p. 1181-1184. 1998.
TAPIA, A., SMITH, J.A., DIXON, M. Estimation of convective rainfall from lightning observations. Journal of Applied Meteorology, v. 37, p. 1497-1509. 1998.

TEIXEIRA V. A. et al. Lightning Density Distribution over Eastern Amazonia, from 10-years Data of Observations by TRMM - LIS. In: XVI International Conference on Atmospheric Eletricity, 2011, Anais... Rio de Janeiro-RJBrasil, 08 a 12 de agosto.

WALISER, D. E.; GAUTIER, C. A satellite-derived climatology of the ITCZ. Journal of Climate, v. 6, n. 11, p. 2162-2174, 1993.

ZHOU, Y., QIE, X., SOULA, S. A study of the relationship between cloud-toground lightning and precipitation in the convective weather system in China. Ann. Geophys. v. 20, p. 107-113. 2002. 